\title{
Audit Operasional, Pengendalian Internal, dan Manajemen Pergudangan: Studi pada Toserba Yogya
}

\author{
Elsa Cintia Anugrah1, Hiro Tugiman², Dedik Nur Triyanto ${ }^{3}$ \\ Fakultas Ekonomi dan Bisnis, Universitas Telkom \\ 1ecintiaanugrah@gmail.com²hiro.tugiman@yahoo.com ${ }^{3}$ dedik.triyanto@gmail.com
}

\begin{abstract}
In a trading company, inventory is an asset that needs to be managed properly. The objective of this study is to determine the influence of operational audit and internal control on warehouse management of Yogya Mitrabatik department store Tasikmalaya. This study is using descriptive and multiple linear regression analysis method. Sample of the study are 50 employees whoinvolved in the warehouse management and internal auditors. The study found that all of the variables have been implemented well. The operational audit and internal control influence the warehouse management significantly and simultaneously with 0.337 determination coefficient score. While partially, only internal control that significantly and positively influence on the warehouse management. This research implies that the store should increase the control of their inventory.
\end{abstract}

Keywords : operational audit, internal control, warehouse management

\begin{abstract}
Abstrak
Pada perusahaan dagang, persediaan merupakan aktiva yang harus dikelola dengan baik. Tujuan dari penelitian ini adalah mengetahui pengaruh audit operasional dan pengendalian intern terhadap manajemen pergudangan Toserba Yogya Mitrabatik Tasikmalaya. Penelitian ini menggunakan metode analisis deskriptif dan regresi linier berganda. Sampel penelitian yaitu 50 orang karyawan yang terlibat dalam pengelolaan gudang dan auditor internal. Hasil penelitian menunjukkan bahwa seluruh variabel telah dilaksanakan dengan baik. Secara simultan, audit operasional dan pengendalian intern berpengaruh signifikan terhadap manajemen pergudangan dengan koefisien determinasi sebesar 0,337. Secara parsial, hanya pengendalian internal yang berpengaruh positif signifikan terhadap manajemen pergudangan. Hasil ini berimplikasi bahwa Toserba harus meningkatkan pengawasan terhadap persediannya.
\end{abstract}

Kata kunci: audit operasional, pengendalian internal, manajemen pergudangan

Diterima: 04 April 2017; Direvisi: 25 April 2017; Disetujui: 10 Mei 2017 


\section{PENDAHULUAN}

Persediaan barang merupakan aktiva lancar yang material dalam laporan neraca perusahaan. Menurut Ogbo, dkk. (2014), inventory is among the largest investment made and therefore logically deserves to be treated as amojor polycy variable, highly responsive to the plans and style of top management. Pada perusahaan dagang, persediaan barang tidak diproses lagi, tetapi akan langsung dijual kembali. Oleh karena itu, pengelolaan persediaan harus dilakukan dengan baik agar kualitas produk tidak menurun.

Sebagai salah satu perusahaan dagang yang bergerak dalam bidang ritel, Toserba Yogya merupakan perusahaan yang cukup besar dan terkenal khususnya di wilayah Jawa Barat. Namun pada pemeriksaan yang dilakukan oleh Dinas KUMKM Perindag Kota Tasikmalaya pada tanggal 16 Juni 2016, ditemukan barang dagangan yang tidak layak konsumsi masih dijual di Toserba YOGYA Mitrabatik Tasikmalaya berupa tujuh kilogram jeruk yang tidak layak konsumsi karena kondisinya telah keriput dan tekstur jeruk tidak menarik. Diamankan pula satu kaleng biskuit yang sudah rusak.

Kasus tersebut kemungkinan terjadi karena adanya permasalahan mengenai pengelolaan persediaan barang dagangan. Pengelolaan persediaan barang dagangan di gudang diatur dengan dilaksanakannya manajemen pergudangan. Manajemen pergudangan tidak lepas dari aktivitas atau operasi pergudangan. Agar manajemen pergudangan dapat berjalan dengan baik, maka diperlukan pengendalian internal dari manajer atas setiap aktivitas atau operasi pergudangan. Pengendalian intern menurut Committee of Sponsoring Organizations of the Treadway Commission (COSO) yang diadopsi oleh Institut Akuntan Publik Indonesia (IAPI) dalam Agoes (2012) mendefinisikan pengendalian internal sebagai suatu proses yang dijalankan oleh dewan komisaris, manajemen, dan personel lain entitas yang didesain untuk memberikan keyakinan memadai tentang pencapaian tiga golongan tujuan berikut ini: Pertama, kehandalan pelaporan keuangan; Ketiga, efektivitas dan efisiensi operasi; Ketiga, kepatuhan terhadap hukum dan peraturan yang berlaku. 
Pengendalian internal dilakukan oleh manajer dalam mengatur bagaimana jalannya manajemen pergudangan. Berdasarkan pada komponen pengendalian internal, manajer harus dapat menciptakan lingkungan kerja yang sadar mengenai pentingnya pengendalian melalui dibuatnya peraturan dan kebijakan yang dijalankan oleh karyawan yang berkompeten, menilai risiko yang dihadapi, menetapkan aktivitas pengendalian untuk mengatasi risiko tersebut, mengkomunikasikan informasi dengan baik, serta melakukan pemantauan pelaksanaan manajemen pergudangan secara berkelanjutan. Jika manajer dapat melakukan hal-hal tersebut, maka telah tercipta pengendalian internal yang layak. Semakin baik atau layaknya pengendalian internal, maka manajemen pergudangan juga dapat diatur semakin baik lagi.

Demi memastikan pelaksanaan manajemen gudang yang baik, maka diperlukan sebuah evaluasi dari pihak yang independen. Evaluasi tersebut dapat berupa audit operasional yang dilakukan oleh auditor internal atau auditor eksternal. Audit operasional sebagai alat evaluasi terhadap kegiatan, program, ataupun bagian perusahaan akan memeriksa dan melaporkan bagaimana manajemen pergudangan yang telah dilaksanakan mengenai apakah pada setiap aktivitasnya sumber daya telah digunakan secara efisien dan ekonomis, menilai efektivitas manajemen pergudangan dalam mencapai tujuannya, serta mengetahui risiko dan hambatan yang dihadapi. Audit operasional akan menghasilkan rekomendasi untuk perbaikan hal-hal yang masih kurang baik. Oleh karena itu, semakin baik pelaksanaan audit operasional, akan menghasilkan rekomendasi yang dapat dilaksanakan untuk mengatasi permasalahan dalam pengelolaan barang dagang di gudang demi manajemen pergudangan yang lebih baik lagi.

Berdasar pada kasus yang terjadi di Toserba Yogya Mitrabatik Tasikmalaya diatas, dilakukan observasi pendahuluan untuk mengetahui kondisi objek penelitian. Hasil dari observasi tersebut diketahui bahwa terdapat suatu area di luar gudang yang digunakan untuk menyimpan barang dagangan, yang disebut sebagai gudang transit, namun tidak jarang barang tersebut langsung dikeluarkan tanpa dimasukkan ke gudang persediaan dan tanpa didampingi supervisor. Selain itu, area ini dapat dilalui secara bebas oleh seluruh karyawan karena menjadi satu dengan 
area kantor dan loker karyawan tanpa adanya pemisah yang jelas. Akses gudang juga masih belum dibatasi walaupun telah berada pada suatu ruangan khusus. Masalah overload gudang juga diakui oleh store manager masih sering terjadi.

Pemaparan tersebut membuat peneliti tertarik untuk melakukan penelitian untuk mengetahui bagaimana pelaksanaan audit operasional, pengendalian internal, dan manajemen pergudangan, serta pengaruh audit operasional dan penngendalian internal baik secara parsial maupun simultan terhadap manajemen pergudangan Toserba Yogya Mitrabatik Tasikmalaya.

\section{METODE}

Penelitian ini merupakan penelitian deskriptif kuantitatif. Penelitian deskriptif adalah penelitian yang dimaksudkan untuk memperoleh gambaran dari suatu fakta secara sistematis, faktual, dan akurat sehingga dapat diinterpretasikan dengan tepat untuk menganalisis masalah yang diteliti, dan dapat ditarik kesimpulan yang tepat (Naibaho, 2013), sedangkan penelitian kuantitatif adalah metode penelitian yang digunakan untuk meneliti pada populasi atau sampel terrentu, teknik pengambilan sampel pada umumnya dilakukan secara random, pengumpulan data menggunakan instrumen penelitian, analisis data bersifat kuantitatif/statistik dengan tujuan menguji hipotesis yang telah ditetapkan (Sugiyono, 2012).

Populasi adalah wilayah generalisasi yang terdiri atas obyek/subyek yang mempunyai kualitas dan karakteristik tertentu yang ditetapkan oleh peneliti untuk dipelajari dan kemudian ditarik kesimpulannya. Populasi dalam penelitian ini adalah pihak-pihak yang terlibat dalam pengelolaan gudang yang terdiri dari 1 orang store manager, 2 orang receive administrator, 3 orang warehouse keeper, 2 orang checker, dan 86 orang service crew, serta 6 orang auditor internal yang melakukan audit operasional.

Jumlah populasi pada penelitian ini adalah 100 orang. Tingkat kelonggaran ketelitian kesalahan pengambilan sampel dipilih sebesar 10\%, maka jumlah sampel dengan menggunakan rumus Slovin ialah sebanyak 50 orang, kemudian dikurangi dengan strata struktural 8 orang dan auditor internal 6 orang, maka sisa sampel untuk strata service crew sebanyak 36 orang. 
Teknik analisis yang akan dipergunakan dalam penelitian ini ialah analisis regresi berganda. Analisis regresi berganda digunakan untuk meramalkan bagaimana keadaan (naik turunnya) variabel dependen, bila dua atau lebih variabel independen sebagai faktor prediktor dimanipulasi. Adapun persamaan regresi berganda dua prediktor yang digunakan adalah:

$$
M P_{i}=\alpha+\beta_{1} A O_{i}+\beta_{2} P I_{i}+\varepsilon_{i}
$$

Dimana:

MP ialah manajemen pergudangan

AO ialah audit operasional

PI ialah pengendalian intern

\section{HASIL DAN PEMBAHASAN}

\section{Analisis Deskriptif}

Analisis deskriptif menggunakan data yang telah dikumpulkan melalui kuesioner dari 50 orang responden dengan hasil akhir sebagai berikut:

Tabel 1. Klasifikasi Interpretasi Variabel Audit Operasional

\begin{tabular}{clcc}
\hline No. & \multicolumn{1}{c}{ Indikator } & Persentase (\%) & Interpretasi \\
\hline 1 & Efisiensi & 77.04 & Baik \\
2 & Efektivitas & 84.50 & Sangat Baik \\
3 & Rekomendasi Perbaikan & 78.64 & Baik \\
\hline & Jumlah & 240.18 & \multirow{2}{*}{ Baik } \\
\hline
\end{tabular}

Sumber: data diolah

Berdasarkan hasil kuesioner, indikator efisiensi dinilai baik dengan skor 77.04\% yang menunjukkan bahwa responden menilai audit operasional yang dilakukan terhadap manajemen pergudangan telah memperhatikan biaya untuk mencapai hasil yang lebih besar walaupun fasilitas di gudang dianggap belum sesuai jumlah barang dan audit operasional dianggap belum selalu bisa menemukan bagian yang mengalami pemborosan biaya.

Indikator efektivitas dinilai sangat baik dengan skor $84.50 \%$ yang menunjukkan bahwa responden menilai audit operasional yang dilakukan terhadap manajemen pergudangan telah mencapai tujuan manajemen pergudangan didukung dengan pemanfaatan gudang yang telah maksimal dan tata letak barang yang disusun 
berdasarkan jenis dan kelompok kedatangan barang. Tetapi ada 10 orang responden menganggap audit operasional belum selalu dapat menunjukkan bagian yang menjadi kelemahan atupun kekuatan dari manajemen pergudangan. Indikator rekomendasi perbaikan dinilai baik dengan skor 78.64\% yang menunjukkan bahwa responden menilai audit operasional yang dilakukan terhadap manajemen pergudangan telah memberikan rekomendasi yang dapat diterapkan oleh perusahaan, walaupun rekomendasi yang telah dilaksanakan masih belum mampu menyelesaikan permasalahan yang dihadapi seperti masalah overload gudang.

Menurut Permatasari (2014) meskipun auditor boleh memberikan rekomendasi untuk perubahan dalam operasi, personel operasional harus memiliki kewenangan untuk menerima atau menolak rekomendasi tersebut. Hal ini sejalan dengan hasil wawancara yang diketahui bahwa tidak setiap rekomendasi dapat dilaksanakan karena menurut store manager, rekomendasi tersebut terkadang tidak memperhatikan kemampuan dari perusahaan sehingga sulit untuk dilaksanakan seperti menambah luas gudang karena terbatasnya lahan disekitar perusahaan dan kebutuhan dana untuk pembangunan yang tidak sedikit, serta saran untuk menitipkan barang yang tidak dapat dimasukkan di gudang sendiri ke gudang cabang lain tidak dapat memuat seluruh barang karena selain hanya ada satu cabang yang berada di Kota Tasikmalaya, terbatasnya kapasitas gudang tersebut, diperlukan juga pengawasan yang lebih agar terhindar dari penyalahgunaan.

Tabel 2. Klasifikasi Interpretasi Variabel Pengendalian Internal

\begin{tabular}{clcc}
\hline No. & \multicolumn{1}{c}{ Indikator } & $\begin{array}{c}\text { Persentase } \\
(\mathbf{\% )}\end{array}$ & Interpretasi \\
\hline 1 & Lingkungan Pengendalian & 89.40 & Sangat Baik \\
2 & Penilaian Risiko & 79.47 & Baik \\
3 & Aktivitas Pengendalian & 79.46 & Baik \\
4 & Informasi dan Komunikasi & 75.33 & Baik \\
5 & Pemantauan & 86.40 & Sangat Baik \\
\hline & Jumlah & 410.06 & Baik \\
\hline
\end{tabular}

Sumber: data diolah 
Indikator lingkungan pengendalian dinilai sangat baik dengan skor 89.60\% yang menunjukkan bahwa responden menilai pengendalian internal yang dilakukan terhadap manajemen pergudangan telah menciptakan lingkungan pengendalian yang efektif dimana baik manajemen maupun karyawan telah mengetahui dan memahami tugas, wewenang, dan tanggung jawab masing-masing serta memiliki kompetensi yang baik dalam menjalankannya.

Indikator penilaian risiko dinilai baik dengan skor $79.47 \%$ yang menunjukkan bahwa responden menilai pengendalian internal yang dilakukan terhadap manajemen pergudangan dapat menilai risiko pada setiap aktivitas operasional pergudangan dengan baik dan telah ditentukan langkah untuk menindaklanjutinya, namun penilaian risiko terhadap kelebihan persediaan (overload) dan kekurangan persediaan (stockout) tidak dilakukan sebaik penilaian risiko kerusakan dan kehilangan persediaan.

Indikator aktivitas pengendalian dinilai baik dengan skor $79.46 \%$ yang menunjukkan bahwa responden menilai pengendalian intern yang dilakukan terhadap manajemen pergudangan didukung dengan aktivitas pengendalian yang memadai, walaupun aktivitas pengendalian terhadap pembatasan akses gudang kepada pihak atau karyawan yang berwenang tidak dijalankan. Hal ini terjadi karena tidak adanya batasan akses terhadap gudang dan menyatunya gudang dengan area kantor memungkinkan kecurangan dapat dilakukan dengan mudah.

Indikator informasi dan komunikasi dinilai baik dengan skor 75.33\%. Hal ini menunjukkan bahwa responden menilai pengendalian intern yang dilakukan terhadap manajemen pergudangan dapat menyampaikan informasi yang andal melalui komunikasi yang baik. Walaupun sistem informasi belum terintegrasi, dengan ditunjang komunikasi antara karyawan dan pimpinannya yang berjalan dengan baik sehingga informasi dapat disampaikan dan diterima dengan baik oleh karyawan. Indikator pemantauan dinilai sangat baik dengan skor $86.40 \%$ yang menunjukkan bahwa pengendalian internal yang dilakukan terhadap manajemen pergudangan telah didukung dengan pemantauan yang sangat baik dimana pimpinan melakukan pemantauan secara berkala dan berkelanjutan serta memperhatikan kelemahan, kendala, dan kecurangan yang mungkin terjadi. 
Tabel 3. Klasifikasi Interpretasi Variabel Manajemen Pergudangan

\begin{tabular}{clcc}
\hline No. & Indikator & Persentase (\%) & Interpretasi \\
\hline 1 & Pemrosesan Pesanan Pembelian & 82,40 & Baik \\
2 & Penerimaan Barang & 84,90 & Sangat Baik \\
3 & Penyimpanan Barang & 83,46 & Baik \\
4 & Pengeluaran Barang & 81,90 & Baik \\
\hline & Jumlah & 332,66 & \multirow{2}{*}{ Baik } \\
\hline
\end{tabular}

Sumber: data diolah

Indikator pemrosesan pesanan pembelian dinilai baik dengan skor $82.40 \%$. Hal ini menunjukkan bahwa responden menilai dalam pemrosesan pesanan pembelian telah terdapat pemisahan tugas yang jelas antara bagian pembelian dan bagian pergudangan. Selain itu, komunikasi telah terjalin dengan baik antara bagian pembelian dan bagian pergudangan.

Indikator penerimaan barang dinilai sangat baik dengan skor 84.90\%. Hal ini menunjukkan bahwa responden menilai pada aktivitas penerimaan barang prosedurnya telah ditentukan dan dipahami dengan baik, memudahkan proses penyimpanan barang, dan menjamin kualitas dan kuantitas barang. Namun barang yang telah diterima dan tidak dapat disimpan di gudang karena terjadinya kelebihan kapasitas, disimpan sementara di gudang transit yang akses tempatnya tidak dibatasi karena gudang transit, loker karyawan, dan kantor bagian pergudangan berada di ruangan yang sama tanpa pemisah yang jelas.

Indikator penyimpanan barang dinilai dengan skor $83.46 \%$ yang menunjukkan bahwa aktivitas penyimpanan barang di dalam gudang telah sesuai dengan prosedurnya, dimana barang yang telah diterima akan langsung disimpan ke dalam gudang serta disusun sesuai dengan klasifikasi jenis barang dan kelompok kedatangan untuk menghindari barang kadaluarsa karena tersimpan terlalu lama. Namun barang yang disimpan di gudang transit memang menunggu cukup lama untuk bisa disimpan di gudang karena penuhnya kapasitas gudang.

Indikator pengeluaran barang dinilai dengan skor $81.90 \%$ yang menunjukkan bahwa prosedur aktivitas pengeluaran barang telah ditetapkan dan dipahami dengan baik, dimana barang yang akan dikeluarkan merupakan barang yang telah disimpan lebih lama serta telah diperiksa kualitas dan kuantitasnya oleh 
checker. Barang yang cacat tidak dapat dikeluarkan ke toko dan dipisahkan dari barang yang baik. Namun pengeluaran barang tidak didasarkan dokumen permintaan barang karena Service crew atau sales promotion girls/boys yang memerlukan barang dapat langsung mengeluarkan barang tanpa memberikan keterangan kepada supervisor. Hal ini mengakibatkan meningkatnya kemungkinan barang cacat yang masuk ke toko karena tanpa pengawasan supervisor, kecurangan berupa kerjasama antara checker dan service crew untuk mengurangi tingkat kerusakan barang di gudang menjadi lebih mudah.

Tabel 4. Hasil Uji Validitas

\begin{tabular}{|c|c|c|c|c|}
\hline Variabel & Indikator & Item & r hitung & Keterangan \\
\hline \multirow[t]{15}{*}{ Audit Operasional (X1) } & Efisiensi & A1 & 0.752 & Valid \\
\hline & & $\mathrm{A} 2$ & 0.728 & Valid \\
\hline & & A3 & 0.659 & Valid \\
\hline & & A4 & 0.669 & Valid \\
\hline & & A5 & 0.673 & Valid \\
\hline & Efektivitas & A6 & 0.230 & Tidak Valid \\
\hline & & A7 & 0.737 & Valid \\
\hline & & A8 & 0.37 & Valid \\
\hline & & A9 & 0.28 & Valid \\
\hline & & A10 & 0.752 & Valid \\
\hline & Rekomendasi & A11 & 0.551 & Valid \\
\hline & Perbaikan & A12 & 0.608 & Valid \\
\hline & & A13 & 0.577 & Valid \\
\hline & & A14 & 0.737 & Valid \\
\hline & & A15 & 0.641 & Valid \\
\hline \multirow{15}{*}{$\begin{array}{l}\text { Pengendalian Intern } \\
\text { (X2) }\end{array}$} & Lingkungan & $\mathrm{P} 1$ & 0.648 & Valid \\
\hline & Pengendalian & $\mathrm{P} 2$ & 0.394 & Tidak Valid \\
\hline & & P3 & 0.829 & Valid \\
\hline & Penilaian Risiko & P4 & 0.638 & Valid \\
\hline & & P5 & 0.684 & Valid \\
\hline & & P6 & 0.603 & Valid \\
\hline & Aktivitas & P7 & 0.829 & Valid \\
\hline & Pengendalian & P8 & 0.652 & Valid \\
\hline & & P9 & 0.759 & Valid \\
\hline & Informasi dan & P10 & 0.586 & Valid \\
\hline & Komunikasi & P11 & 0.610 & Valid \\
\hline & & P12 & 0.839 & Valid \\
\hline & Pemantauan & P13 & 0.930 & Valid \\
\hline & & P14 & 0.764 & Valid \\
\hline & & P15 & 0.764 & Valid \\
\hline
\end{tabular}




\begin{tabular}{clccc}
\hline Variabel & \multicolumn{1}{c}{ Indikator } & Item & r hitung & Keterangan \\
\hline Manajemen & Pemrosesan & G1 & 0.717 & Valid \\
Pergudangan (Y) & Pesanan Pembelian & G2 & 0.757 & Valid \\
& & G3 & 0.723 & Valid \\
& Penerimaan & G4 & 0.594 & Valid \\
& Barang & G5 & 0.576 & Valid \\
& & G6 & 0.787 & Valid \\
& Penyimpanan & G7 & 0.733 & Valid \\
& Barang & G8 & -0.280 & Tidak Valid \\
& & G9 & 0.612 & Valid \\
& & G10 & 0.787 & Valid \\
& Pengeluaran Barang & G11 & 0.601 & Valid \\
& & G13 & 0.579 & Valid \\
& & G14 & 0.578 & Valid \\
& & G15 & 0.787 & Valid \\
& & & & Valid \\
\hline
\end{tabular}

Sumber: data diolah

\section{Uji Validitas}

Uji validitas digunakan untuk mengetahui kelayakan item-item pernyataan pada kuesioner dalam menjelaskan atau mengukur suatu variabel. Uji validitas dilakukan terhadap sepuluh responden pada populasi yang serupa dengan populasi penelitian. Kriteria uji validitas yang digunakan yaitu jika koefisien korelasi product moment $(r$ hitung) $>r$ tabel $(\alpha ; n-2) n=j u m l a h$ sampel, maka item tersebut dapat digunakan dalam kuesioner.

Nilai $r$ tabel dengan tingkat signifikansi $\alpha=0,1$ dan $n-2=8$ adalah 0,5494 . Uji validitas dilakukan terhadap 45 item pernyataan. Setelah diuji, terdapat 3 item yang memiliki nilai $r$ hitung < r tabel, yaitu yaitu item A6, P2, dan G8 yang dinyatakan tidak valid. Item yang tidak valid tersebut dihapus dari kuesioner sehingga kuesioner terdiri dari 42 item pernyataan.

\section{Uji Reliabilitas}

Uji reliabilitas digunakan untuk mengetahui kemampuan suatu instrumen penelitian dalam menyediakan data yang andal dan dapat dipercaya. Kriteria yang digunakan adalah bila instrumen memiliki koefisien Cronbach's Alpha > .,6 maka instrumen tersebut dinyatakan andal. Hasil pengujian menunjukkan bahwa koefisien Cronbach's Alpha untuk seluruh variabel telah lebih besar daripada 0.6 sehingga dapat disimpulkan bahwa instumen telah andal atau reliabel dalam 
menyediakan data penelitian.

Tabel 5. Hasil Uji Reliabilitas

\begin{tabular}{lccc}
\hline \multicolumn{1}{c}{ Variabel } & Cronbach's Alpha & Kriteria & Keterangan \\
\hline Audit Operasional & 0.909 & 0.6 & Reliabel \\
Pengendalian Intern & 0.931 & 0.6 & Reliabel \\
Manajemen Pergudangan & 0.917 & 0.6 & Reliabel \\
\hline
\end{tabular}

Sumber: data diolah

\section{Hasil Empiris}

Setelah dilakukan uji validitas dan reliabilitas data, kemudian diikuti dengan uji asumsi klasik. Maka selanjutnya akan dilakukan regresi linier berganda. Tabel 6 menunjukkan hasil estimasi dengan menggunakan regresi linier berganda.

Tabel 6. Hasil Uji Regresi Linier Berganda

\begin{tabular}{lcccc}
\hline \multicolumn{1}{l}{} & B & Std Error & t & Sig \\
\hline Constant & .391 & .396 & .987 & .329 \\
Audit operasional & .257 & .177 & 1.447 & .154 \\
Pengendalian & .410 & .146 & 2.801 & .007 \\
internal & & & & \\
\hline R-square & .364 & & F-stat & 13.449 \\
Adj R-square & .337 & & Sig & .000 \\
\hline
\end{tabular}

Sumber: Data diolah

Berdasarkan Tabel 6, maka dapat diperoleh model atau persamaan regresi sebagai berikut:

$$
\mathrm{MP}=0,391+0,257 \mathrm{AO}+0,410 \mathrm{MP}
$$

Berdasarkan hasil empiris, nilai konstanta sebesar 0.391 berarti jika audit operasional dan pengendalian internal bernilai 0 , maka nilai manajemen pergudangan adalah 0.391. Nilai koefisien variabel audit operasional sebesar 0.257 berarti bahwa manajemen pergudangan mengalami peningkatan sebesar 0.257 satuan jika audit operasional mengalami peningkatan sebesar 1 satuan, dengan asumsi variabel pengendalian internal bernilai tetap. Nilai koefisien variabel pengendalian intern sebesar 0.410 berarti bahwa manajemen pergudangan mengalami peningkatan sebesar 0.410 satuan pengendalian intern mengalami peningkatan sebesar 1 satuan, dengan asumsi variabel audit operasional bernilai tetap.

Nilai koefisien determinasi (adjusted $R \quad$ Square) sebesar 0.337 
menunjukkan kemampuan variabel audit operasional dan pengendalian intern dalam menerangkan variasi variabel dependen, yaitu manajemen pergudangan dalam model regresi hanya 0.337 atau $33.70 \%$. Sedangkan variabel-variabel lain yang tidak diteliti dalam penelitian ini memiliki pengaruh sebesar $66.30 \%$ dalam pelaksanaan manajemen pergudangan.

Uji F untuk digunakan untuk mengetahui ada atau tidaknya pengaruh bersama-sama dari variabel independen terhadap variabel dependen. Dalam penelitian ini, penulis menggunakan uji $\mathrm{F}$ untuk mengetahui pengaruh signifikan variabel audit operasional dan pengendalian intern terhadap manajemen pergudangan secara simultan. Berdasarkan Tabel 6, dapat dilihat bahwa nilai $\mathrm{F}$ hitung sebesar 13.449. Nilai F menunjukkan bahwa nilai F hitung > F tabel Sesuai dengan kriteria yang telah ditetapkan, maka $\mathrm{H}_{0}$ ditolak dan $\mathrm{H}_{a}$ diterima, sehingga audit operasional dan pengendalian intern berpengaruh signifikan secara simultan terhadap manajemen pergudangan.

Berdasarkan Tabel 6, dapat dilihat bahwa nilai t hitung sebesar 1.447 sedangkan nilai t tabel untuk tingkat probabilitas $0,1 \mathrm{dan} \mathrm{df}=47$ adalah 1.6779. Jika dibandingkan, dapat diketahui bahwa nilai t hitung $<$ t tabel yaitu $1.447<1.6779$. Sesuai dengan kriteria yang telah ditetapkan, dapat disimpulkan bahwa $\mathrm{H}_{0}$ diterima dan $\mathrm{H}_{\mathrm{a}}$ ditolak, sehingga audit operasional tidak berpengaruh signifikan secara parsial terhadap manajemen pergudangan Toserba Yogya Mitrabatik Tasikmalaya. Hasil uji t menunjukkan bahwa audit operasional tidak berpengaruh signifikan terhadap manajemen pergudangan. Hal ini berarti bahwa seberapa baik pun pelaksanaan audit operasional, tidak akan memberikan pengaruh dalam pelaksanaan manajemen pergudangan di Toserba Yogya Mitrabatik Tasikmalaya.

Audit operasional tidak berpengaruh dapat disebabkan karena pada hasil kuesioner diketahui bahwa audit operasional tidak selalu dapat menemukan bagian yang mengalami pemborosan. Peralatan di gudang belum cukup menunjang aktivitas pergudangan walaupun auditor telah memberikan rekomendasi untuk perbaikan, namun masalah terkait peralatan belum dapat teratasi. Penggunaan gudang transit dapat menghindari biaya pengembangan gudang, namun dengan keadaan gudang transit yang bersatu dengan kantor tanpa pemisah yang jelas 
membuat kemungkinan terjadinya kecurangan semakin tinggi. Hal ini menunjukkan bahwa walaupun auditor dapat menunjukkan pentingnya masalah tersebut, namun gudang transit masih digunakan tanpa adanya peningkatan keamanan.

Berdasarkan hasil wawancara dan observasi, didapatkan informasi bahwa rekomendasi yang diberikan auditor tidak selalu dapat dilaksanakan karena adanya keterbatasan. Menurut store manager, rekomendasi tersebut terkadang tidak memperhatikan kemampuan dari perusahaan sehingga sulit untuk dilaksanakan seperti menambah luas gudang karena terbatasnya lahan disekitar perusahaan dan kebutuhan dana untuk pembangunan yang tidak sedikit, serta saran untuk menitipkan barang yang tidak dapat dimasukkan di gudang sendiri ke gudang cabang lain tidak dapat memuat seluruh barang karena selain hanya ada satu cabang yang berada di Kota Tasikmalaya membuat terbatasnya kapasitas gudang, diperlukan juga pengawasan yang lebih agar terhindar dari penyalahgunaan.

Selain itu, audit operasional dilakukan oleh auditor internal, namun auditor internal tidak berada di setiap cabang karena auditor yang bertanggungjawab di setiap cabang berkantor atau berada di Toserba Yogya HZ Mustofa Tasikmalaya yang merupakan cabang pusat untuk wilayah Priangan Timur. Selain itu, jumlah auditor internal pun terbatas, yaitu 6 orang dengan tanggungjawab untuk 7 cabang di wilayah Priangan Timur, sehingga dikhawatirkan audior internal tidak mengetahui atau memahami secara sangat rinci aktivitas di setiap cabang, terutama aktivitas pergudangan. Pemahaman yang kurang baik terhadap objek yang diaudit dapat menyebabkan rekomendasi yang dihasilkan tidak tepat sasaran dan sulit untuk dapat dilaksanakan. Hasil ini sejalan dengan penelitian yang dilakukan olehIntan Permatasari dan Norita yang meneliti mengenai efektivitas pelayanan kesehatan rawat jalan di Rumah Sakit Al-Islam Bandung.

Berdasarkan Tabel 6, dapat dilihat bahwa nilai t hitung sebesar 2.801 sedangkan nilai t tabel untuk tingkat probabilitas $0,1 \mathrm{dan} \mathrm{df}=47$ adalah 1.6779 . Jika dibandingkan, dapat diketahui bahwa nilai t hitung $>\mathrm{t}$ tabel yaitu $2.801>1.6779$. Sesuai dengan kriteria yang telah ditetapkan, dapat disimpulkan bahwa $\mathrm{H}_{0}$ ditolak dan $\mathrm{H}_{a}$ diterima, sehingga audit operasional berpengaruh signifikan secara parsial 
terhadap manajemen pergudangan Toserba Yogya Mitrabatik.

Selain nilai t, pada Tabel 6 juga dapat dilihat nilai beta untuk variabel pengendalian intern sebesar 0.432 . Nilai beta yang positif menunjukkan bahwa variabel pengendalian intern memiliki pengaruh yang positif terhadap variabel manajemen pergudangan. Hal ini berarti semakin baik pelaksanaan pengendalian intern, maka manajemen pergudangan akan dapat terlaksana semakin baik lagi.

Berdasarkan hasil kuesioner, pelaksanaan pengendalian intern telah baik bahkan untuk indikator lingkungan pengendalian dan pemantauan berada pada klasifikasi sangat baik. Indikator lingkungan pengendalian mencapai nilai $89.40 \%$ berarti bahwa manajemen telah memahami arti pentingnya pengendalian melalui dibuatnya aturan-aturan dan didukung dengan tenaga kerja yang dapat memahaminya dengan baik, sehingga telah tercipta lingkungan pengendalian yang efektif. Terbukti dengan adanya aturan berupa prosedur, membuat pelaksanaan manajemen pergudangan menjadi lebih baik karena setiap aktivitas pergudangan telah mengikuti prosedur tersebut. Indikator pemantauan mencapai nilai $86.40 \%$ yang berarti bahwa pimpinan melakukan pemeriksaan terhadap pelaksanaan manajemen pergudangan dengan baik secara berkala dan berkesinambungan, sehingga masalah yang timbul dapat diketahui dan ditanggapi dengan cepat.

Indikator aktivitas pengendalian memiliki nilai paling rendah yaitu $75.33 \%$ walaupun termasuk baik, hal ini menunjukkan masih terdapat kekurangan dalam aktivitas pengendalian. Pemisahan fungsi dan tugas telah jelas dan dilaksanakan dengan baik antara bagian pembelian atau buyer dengan bagian gudang atau receiving membuat pengelolaan barang yang diterima dari pemasok dapat dikendalikan dengan baik, setiap dokumen telah diotorisasi dan diarsip dengan baik seperti pada laporan penerimaan dan pengeluaran barang akan diotorisasi oleh pihak terkait. Dari hasil wawancara didapat informasi bahwa setiap pesanan pembelian yang bernilai lebih dari $\mathrm{Rp} 5.000 .000,00$ harus diotorisasi oleh store manager dengan mempertimbangkan jumlah persediaan dan kapasitas gudang yang tersedia salah satu tujuannya untuk menghindari kemungkinan terjadi overload gudang karena pembelian barang yang tidak perlu dalam jumlah yang besar. Sedangkan kekurangannya adalah akses terhadap gudang masih belum dibatasi, 
dengan kata lain seluruh karyawan dapat mengakses gudang dengan bebas, sehingga kemungkinan terjadinya kecurangan akan tinggi.

Berdasarkan wawancara dan observasi, didapatkan informasi mengenai keadaan gudang yang tidak dilengkapi pintu dengan kunci otomatis atau alat akses lainnya. Selain itu, area gudang transit juga menyatu dengan tempat kerja dan loker karyawan, sehingga pemeriksaan keamanan tidak dilakukan di pintu gudang, tetapi di pintu area tempat kerja karyawan. Pengendalian internal berpengaruh positif signifikan terhadap manajemen pergudangan sejalan dengan hasil penelitian yang dilakukan oleh Rapina dan Christyanto (2011) mengenai efektivitas dan efisiensi kegiatan operasional pada siklus persediaan dan pergudangan, serta 3 penelitian lainnya yang dilakukan oleh Hariyati dan Olivianti (2013); Ogbo, dkk. (2014); serta Leng dan Zhao (2013) mengenai kinerja perusahaan.

\section{SIMPULAN}

Pada manajemen pergudangan Toserba Yogya Mitrabatik Tasikmalaya, audit operasional telah dilaksanakan dengan baik dan mencapai nilai $80.06 \%$, hal ini menunjukkan bahwa audit operasional telah memperhatikan efisiensi dan efektivitas manajemen pergudangan, serta dapat memberikan saran atau rekomendasi perbaikan. Pengendalian intern telah dilaksanakan dengan baik dan mencapai nilai $82.01 \%$, hal ini menunjukkan bahwa lingkungan pengendalian telah efektif dalam penerapan komponen lainnya untuk mencapai pelaksanaan manajemen pergudangan yang efektif dan efisien. Sedangkan pelaksanaan manajemen pergudangan Toserba Yogya Mitrabatik Tasikmalaya telah dilaksanakan dengan baik dan mencapai nilai $83.16 \%$.

Oleh karena itu, sebaiknya auditor selalu mengawasi pelaksanaan rekomendasi dan jumlah auditor ditambah agar lebih memahami operasi perusahaan sehingga menghasilkan rekomendasi yang dapat dilaksanakan perusahaan dan dapat menyelesaikan masalah yang ada. Untuk peningkatan pengendalian internal, manajemen perusahaaan sebaiknya meningkatkan fasilitas gudang, memperhatikan ketepatan dalam menghitung kapasitas agar terhindar dari kelebihan kapasitas gudang (overload), memisahkan gudang transit dari area kantor, serta membatasi akses terhadap gudang. 


\section{PUSTAKA ACUAN}

Agoes, S. (2012). Auditing Petunjuk Praktis Pemeriksaan Akuntan oleh Akuntan Publik (Edisi 4 volume 1). Jakarta: Salemba Empat.

Hariyati, R. Maryuni \& O.D. Olivianti. (2013). Pengaruh Audit Manajemen dan Pengendalian Intern terhadap Kinerja Perusahaan dengan Good Corporate Governance sebagai Variabel Intervening (Studi pada PT Jamsostek (Persero) Divisi Regional VI Jawa Timur). Prosiding Seminar Nasional SANCALL 2013.

Leng, J. \& P. Zhao. (2013). Study on the Impact of the Quality of Internal Control on the Permormance of M\&A. Journal of Science and Management,Vol. 6: 223231.

Naibaho, A.T. (2013). Analisis Pengendalian Internal Persediaan Bahan Baku Terhadap Efektifitas Pengelolaan Persediaan Bahan Baku. Jurnal EMBA .Vol. $1(3): 63-70$.

Ogbo, A.I., O.I. Victoria., \& W.I. Ukpere. (2014). The Impact of Effective Inventory Control Management on Organizational Performance: A Study of 7up Bottling Company Nile Mile Enugu, Nigeria. Mediterranean Journal of Social Science. Vol. 5 (10): 109-120.

Permatasari, I.. (2014). Pengaruh Audit Operasional dan Pengendalian Intern terhadap Efektivitas Pelayanan Kesehatan Rawat Jalan Rumah Sakit (Studi kasus pada Rumah Sakit Al-Islam Bandung). (Skripsi tidak dipublikasikan). Bandung: Universitas Telkom

Rapina dan Leo Christyanto. (2011). Peranan Sistem Pengendalian Internal dalam Meningkatkan Efektivitas dan Efisiensi Kegiatan Operasional pada Siklus Persediaan dan Pergudangan (Studi kasus pada PT Ultrajaya Milk Industry \& Trading Company Tbk. Bandung). Akurat Jurnal Ilmiah Akuntansi No. 6 Tahun ke-2 September-Desember 2011

Sugiyono. (2012). Metode Penelitian Bisnis (Cetakan 16). Bandung: Alfabeta. 